SANDIA REPORT

SAND96-0413 - UC-126

Unlimited Release

Printed June 1996

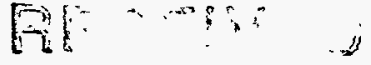

JUL 15 19ง

OSTI

\title{
Log Analysis of Six Boreholes in Conjunction with Geologic Characterization Above and on Top of the Weeks Island Salt Dome
}

\section{Allan R. Sattler}

Prepared by

Sandia National Laboratories

Albuquerque, New Mexico 87185 and Livermore, California 94550 for the United States Department of Energy under Contract DE-AC04-94AL85000 ?

Approved for public release; distribution is unlimited.

If

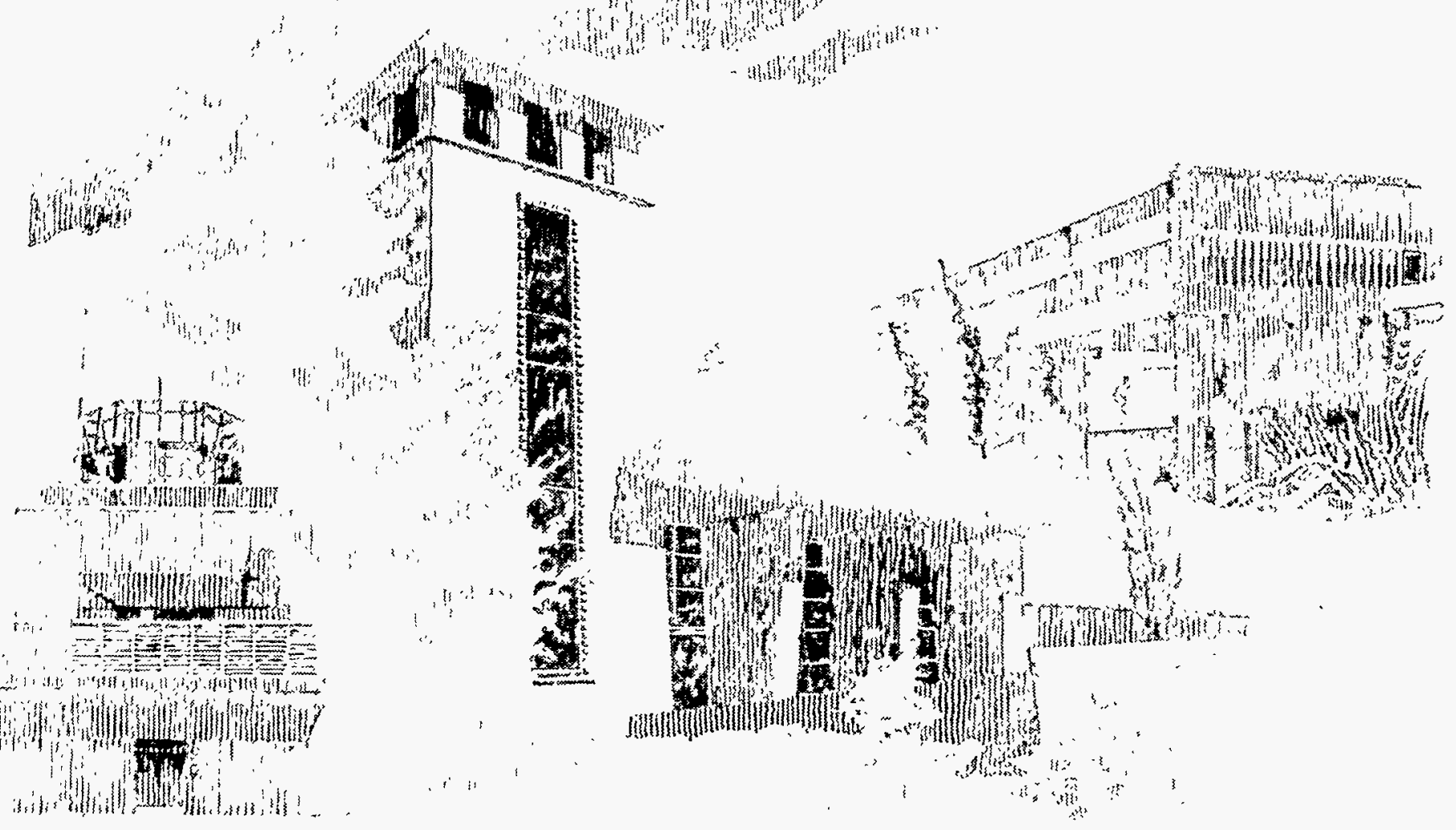


Issued by Sandia National Laboratories, operated for the United States Department of Energy by Sandia Corporation.

NOTICE: This report was prepared as an account of work sponsored by an agency of the United States Government. Neither the United States Government nor any agency thereof, nor any of their employees, nor any of their contractors, subcontractors, or their employees, makes any warranty, express or implied, or assumes any legal liability or: responsibility for the accuracy, completeness, or usefulness of any information, apparatus, product, or process disclosed, or represents that its use would not infringe privately owned rights. Reference herein to any specific commercial product, process, or service by trade name, trademark, manufacturer, or otherwise, does not necessarily constitute or imply its endorsement, recommendation, or favoring by the United States Government, any agency thereof or any of their contractors or subcontractors. The views and opinions expressed herein do not necessarily state or reflect those of the United States Government, any agency thereof or any of their contractors.

Printed in the United States of America. This report has been reproduced directly from the best available copy.

Available to DOE and DOE contractors from

Office of Scientific and Technical Information

PO Box 62

Oak Ridge, TN 37831

Prices available from (615) 576-8401, FTS 626-8401

Available to the public from

National Technical Information Service

US Department of Commerce

5285 Port Royal Rd

Springfield, VA 22161

NTIS price codes

Printed copy: $\mathrm{A03}$

Microfiche copy: A01 
SAND 96-0413

Distribution

Unlimited Release

Category UC-126

Printed June 1996

\title{
LOG ANALYSIS OF SIX BOREHOLES IN CONJUNCTION WITH GEOLOGIC CHARACTERIZATION ABOVE AND ON TOP OF THE WEEKS ISLAND SALT DOME
}

\author{
Allan R. Sattler \\ Underground Storage Technology Department
}

Prepared by Sandia National Laboratories

Albuquerque, NM 87185 and Livermore, CA 94550

for the U.S. DOE under Contract DE-AC04-94AL85000

\section{DISCLAIMER}

This report was prepared as an account of work sponsored by an agency of the United States Government. Neither the United States Government nor any agency thereof, nor any of their employees, makes any warranty, express or implied, or assumes any legal liability or responsibility for the accuracy, completeness, or usefulness of any information, apparatus, product, or process disclosed, or represents that its use would not infringe privately owned rights. Reference herein to any specific commercial product, process, or service by trade name, trademark, manufacturer, or otherwise does not necessarily constitute or imply its endorsement, recommendation, or favoring by the United States Government or any agency thereof. The views and opinions of authors expressed herein do not necessarily state or reflect those of the United States Government or any agency thereof. 
Intentionally left blank 


\section{ABSTRACT}

Six boreholes were drilled during the geologic characterization and diagnostics of the Weeks Island sinkhole that is over the two-tiered salt mine which was converted for oil storage by the U. S. Strategic Petroleum Reserve. These holes were drilled to provide for geologic characterization of the Weeks Island Salt Dome and its overburden in the immediate vicinity of the sinkhole (mainly through logs and core); to establish a crosswell configuration for seismic tomography; to establish locations for hydrocarbon detection and tracer injection; and to provide direct observations of sinkhole geometry and material properties. Specific objectives of the logging program were to: (1) identify the top of and the physical state of the salt dome; (2) identify the water table; (3) obtain a relative salinity profile in the aquifer within the alluvium, which ranges from the water table directly to the top of the Weeks Island salt dome; and (4) identify a reflecting horizon seen on seismic profiles over this salt dome. Natural gamma, neutron, density, sonic, resistivity and caliper logs were run. Neutron and density logs were run from inside the well casing because of the extremely unstable condition of the deltaic alluvium overburden above the salt dome. The logging program provided important information about the salt dome and the overburden in that (1) the top of the salt dome was identified at $\sim 189 \mathrm{ft} \mathrm{bgl} \mathrm{(103} \mathrm{ft}$ $\mathrm{msl}$ ), and the top of the dome contains relatively few fractures; (2) the water table is approximately $1 \mathrm{ft} \mathrm{msl}$, (3) this aquifer appears to become steadily more saline with depth; and (4) the water saturation of much of the alluvium over the salt dome is shown to be influenced by the prevalent heavy rainfall. Drilling data alone could not provide much of the fine detail derived from depth-dependent properties of the salt dome top, the brine, and alluvium above the dome, or detail of hole rugosity. However, strong indications of a seismic reflector (other than possibly the important water table and the salt-alluvium contacts) were not observed. There is an ambiguity in the top of the water table from one of the wells in the immediate vicinity of the sinkhole in that the interpretation of the log data is inconsistent with in-situ permeability data of the alluvium. Nonetheless, this logging program, a part of the sinkhole diagnostics, provides unique information about this salt dome and the overburden. 
Intentionally left blank 
TABLE OF CONTENTS

Log Analysis of Six Boreholes in Conjunction with Geologic Characterization

Above and on Top of the Weeks Island Salt Dome

$\begin{array}{ll}\text { INTRODUCTION } & 1\end{array}$

BACKGROUND AND GEOLOGIC SETTING

OBJECTIVES OF LOGGING PROGRAM, WHAT INFORMATION ABOUT THE SALT DOME WAS DESIRED

GENERAL LOGGING CONSIDERATIONS 3

DETERMINATION OF TOP OF SALT AND PHYSICAL STATE OF THE TOP OF THE DOME

WATER TABLE DETERMINATION 4

EFFECT OF DRENCHING RAIN ON THE NEUTRON LOG 4

DISCUSSION OF A POSSIBLE DEPRESSION, CONING, IN THE WATER TABLE

SHAPE OF THE ELECTRIC LOGS INFERS INFORMATION ABOUT THE SALINITY PROFILE OF AQUIFER ABOVE THE SALT DOME

CORRELATION OF LOG DATA WITH SEISMIC REFLECTORS 6

SUMMARY OF INFORMATION OBTAINED ABOUT WEEKS ISLAND DOME FROM LOGGING PROGRAM 7

REFERENCES 9 


\section{LIST OF TABLES}

1 Summary of Logging Program

2 Weeks Island Salt and Water Table Correlations at Sinkhole

\section{LIST OF FIGURES}

1 Diagrammatic representation of Sinkhole \#1 throat

2 Geomechanical modeling for crack development 14

3 Open hole electric $\log$ for $\mathrm{BH}-5 \quad 15$

4 Cased hole BH-5 neutron log 16

$5 \quad$ Open hole sonic log in BH-5 17

6 Cased hole neutron $\log$ in $\mathrm{BH}-4 \quad 18$

7 Cased neutron, density, and gamma ray logs in BH-9 19 


\section{INTRODUCTION}

A sinkhole measuring $36 \mathrm{ft}$ across and $30 \mathrm{ft}$ deep was first observed in alluvium overlying the Weeks Island Salt Dome in May 1992 ( Neal, October 1995). It appeared to be about a year old based on initial surface appearance and subsequent reverse extrapolation of growth rates. The position of the sinkhole is directly over the edges of the U. S. Department of Energy(DOE)/Strategic Petroleum Reserve Oil Storage Cavern, a former room-and-pillar salt mine. The association of sinkholes over mines is well established, and this occurrence suggested that groundwater influx was probably causing salt dissolution at shallow depth and associated collapse of overburden at the surface. Leaks of groundwater into other salt mines in Louisiana and elsewhere led to flooding and eventual abandonment. Consequently, much attention has been and continues to be given to characterizing these sinkholes, and to mitigation of the dissolution process.

The presence and location of the sinkhole and its implications were a cause of concern. Consequently, much attention has been given to characterizing this sinkhole. An important part of this is the characterization of the salt dome near the sinkhole.

This paper deals mainly with one aspect of this characterization: the logging program associated with first six holes, $\mathrm{BH}-3$ thorough $\mathrm{BH}-7$ and $\mathrm{BH}-9$, which were drilled close to the sink hole as a part of this characterization. Four $250 \mathrm{ft}$ vertical wells, BH-3 through $\mathrm{BH}-6$, were positioned and drilled so that crosswell seismic tomography could be conducted across the throat of the sinkhole, Figures 1,2. The 250 foot depth was chosen to leave an approximate $300 \mathrm{ft}$ salt buffer above the top of the upper oil storage cavern at approximately $550 \mathrm{ft}$ bgl. The pre-drilling estimate of the top of the salt dome was approximately $185 \mathrm{ft}$ bgl (Acres, 1987).

The other two wells were slant holes. One well, BH-9, was drilled at approximately 80 degree inclination to end up below the top of the sub surface extension of the surface sinkhole expression. The other slant hole, the BH-7 well, started off at approximately 60 degree inclination and was aimed at the sinkhole throat within the salt at depth. It penetrated the top of salt at a normal, vertical depth of $185 \mathrm{ft}$ and continued on through salt into a major sand filled void approximately 72 feet below the top of salt.

Both open hole and cased hole logs were run. Extreme hole instability was expected, and encountered in the alluvium. Nonetheless, suites of open hole logs were obtained in three out of four vertical wells. Open hole logs were not run in the slant holes due to hole stability considerations. Because of inconsistencies in the display of neutron logs, repeat cased hole logs were run in three boreholes.

\section{BACKGROUND AND GEOLOGIC SETTING}

The Weeks Island Salt Dome is located 14 mi south of New Iberia, Louisiana and is the central dome in the Five Islands chain along with Belle Isle, Cote Blanche, Avery and 
Jefferson Islands. All five salt domes have been mined because of their near-surface salt and their logistical advantage being located near the Gulf of Mexico and the Intracoastal Waterway. The Weeks Island Mine was opened in 1902 and salt was extracted commercially until 1977. At that time Morton Salt developed a new mine immediately adjacent while the older workings were converted for oil storage. Minor mine leaks of water, thought to be connate (Martinez, 1978 and 1995), had been noted at various times during the 75 years of active mining, but in-mine-grouting was able to control inflow.

The Weeks Island Salt Dome does not have caprock as do most Gulf Coast salt domes. It has a sediment cover consisting of deltaic alluvium of the ancestral Mississippi River. The water table conforms generally with sea level over the dome but fluctuates with topography and the frequent torrential rains. Presumably this aquifer is near to fully saturated just above the salt dome.

\section{OBJECTIVES OF LOGGING PROGRAM, WHAT INFORMATION ABOUT THE SALT DOME WAS DESIRED}

The logging program for Weeks Island wells was undertaken in order to determine:

- The top of the salt near the sinkhole, whether the top of the salt is flat near the sinkhole; and whether the top of the salt was fractured or relatively competent at that location.

- The depth of the water table near the sinkhole, and some information about the salinity of the associated aquifer with depth.

- Whether or not a seismic reflector exists near the sink hole (other than the water table and the top of salt) and, if possible, correlate the log data with a prominent seismic reflector imaged by the Kansas Geological Survey in a shallow high resolution survey (Miller et al in Bauer, 1994).

During the planning of the $\mathrm{BH}-3$ through $\mathrm{BH}-7$, and $\mathrm{BH}-9$ wells, the possibility of some large scale variation in elevation in the top of the salt dome could not be ruled out, especially since seismic data indicated a reflector roughly $150 \mathrm{ft}$ below the surface over much of the area investigated, and approximately $100 \mathrm{ft}$ below the surface near the sinkhole. The depth of the reflector appeared to be influenced by the presence of the sinkhole.

At the time of planning these wells, knowledge of the salinity profile of the aquifer was limited. This aquifer impinged directly on the top of the salt dome. 
A correlation of the major reflectors seen in the seismic reflection surveys with the log data would add confidence to any geologic interpretation/characterization that would arise from this major diagnostic effort.

\section{GENERAL LOGGING CONSIDERATIONS}

The logs run were the three arm caliper log, natural gamma ray log, neutron log, sonic log, electric log, and focused and 4 pi density logs, Table 1.

The alluvium above the salt was quite unstable and, prior to drilling, it was not known if any open hole logs could be run at all. However a fairly complete suite of open hole logs could was run in three out of four vertical wells, Table 1.

The prospect of running radioactive logs in the unstable alluvium was a concern from the earliest planning stages. An agreement was reached with the surface landowner, Morton International Inc., and with DOE/Sandia that the neutron log and the density logs were to be run behind casing for safety considerations. This would degrade the log quality somewhat, especially the density log where casing thickness varied from 11 to $40.5 \mathrm{lb} / \mathrm{ft}$. Many of the neutrons, the gamma rays of the density log, and the natural gamma rays would be scattered or absorbed by the casing itself. The casing is uniform, but evidence of the casing joints was indicated in some short spaced density logs making it difficult to use this log for quantitative measurements .

In BH-3 through 5 water was pumped from the casing before a logging run. Thus, the neutrons, gamma rays from the density log and even the natural gamma rays would have to penetrate less extraneous material. The neutrons and gamma rays from the neutron and density logs would thus penetrate further into the formation.

The neutron $\log$, in a fully would penetrate approximately 15 in into a formation that is saturated (T. Staatz, 1995), thus "empty" casing would enhance neutron penetration. The 4 pi (spherical) density log has an influence about 13 in. The focused density log has a pie shaped influence 1-2 in beyond casing (short spaced log), and approximately 4 in beyond casing, (long spaced log). Thus, this log might be influenced by casing joints (Yearsley, 1991).

Logs depending on statistical interpretation (natural gamma, density, and neutron) were run very slowly, $5 \mathrm{ft} / \mathrm{s}$. This minimizes statistical uncertainties in the display of the log and increase the chance of observing other than the major geologic contrasts in a formation. Other logs, sonic, electric, and caliper and some repeat runs of the statistical logs, were run at 10 and $15 \mathrm{ft} / \mathrm{s}$. 


\section{DETERMINATION OF TOP OF SALT AND PHYSICAL STATE OF THE TOP OF THE DOME}

Many of the logs that were run highlighted the alluvium-salt interface. The natural gamma ray log best shows this interface. Near the sinkhole, Figure 3, Table 2, the interface lies between 187 and $190 \mathrm{ft}$. The top of the salt dome (with the exception of the sinkhole) appears relatively flat. The contrast in the natural gamma ray activity between the top of salt and the overlying alluvium is great enough that the presence of the casing does not interfere with observation of this obvious contrast, Figure 4.

Other logs also show sufficient differences in the responses between the salt and the alluvium because of contrasting properties of these materials. The neutron log is sensitive to the difference between the saturated alluvium and the relatively dry salt. The resistivity (electric) log is sensitive to the difference between the conductive alluvium with saturated brine and nominally dielectric rock salt, Figure 3 . The density log highlights the density difference between the mixture of sand and wood at the bottom of the alluvium and the salt itself. The sonic log, Figure 5 , is sensitive to the difference between the unconsolidated alluvium and apparently competent salt.

The displays of the sonic log, the amplitude, arrival time, and variable density show little to no variation within the salt, indicating a fairly competent formation. The sonic $\log$, Figure 5, indicates that the top of the Weeks Island Dome, near the sinkhole, is competent over the 50-60 feet of salt that this log describes.

\section{WATER TABLE DETERMINATION.}

A primary purpose of the neutron log was to determine the location of the water table. It was expected that the neutron response to the saturated alluvium below the water table would be fairly uniform from the top of the salt to the water table because the detector is traversing saturated alluvium. Furthermore, it was felt that a change in the neutron response would occur as the neutron log was raised from the saturated to the unsaturated alluvium because the neutrons would encounter much less hydrogen. This was expected to occur very close to mean sea level. The neutron log did follow this behavior in four of the six wells $(\mathrm{BH}-3, \mathrm{BH}-4, \mathrm{BH}-7, \mathrm{BH}-9)$, Figures 6,7 . In the two other wells, saturation effects (see below) may mask this effect. The water table appears from +1 to $+3 \mathrm{ft}$ above sea level near the sinkhole, Table 2 .

\section{EFFECT OF DRENCHING RAIN ON THE NEUTIRON LOG}

The first set of logs was run before a series of drenching rains came. In one of the holes, BH-4, Figure 6, a comparison between "pre- and post-deluge" neutron response in the logs indicated that the water table was no longer observable. The response of the alluvium immediately above and below the water table looks similar. Presumably, the unconsolidated, relative high porosity, shallow alluvium above the water table had 
become much more saturated. Repeat neutron logs were run to clarify this: Repeating and comparing these neutron logs in $\mathrm{BH}-4$ a few days later still showed little difference. The "saturated" signature of the neutron log above the water table remained, Figure 6. However it appears that some degree of "normalcy" may be returning to alluvium above the water table in $\mathrm{BH}-4$, Figure 4. The logs of the $\mathrm{BH}-4$ well also show that pumping the water from the casing enhances the neutron response.

The neutron interpretation above provides an explanation for the neutron response of BH-5 and 6 where no water table was found. The drenching rains came before running the neutron log in those wells. Presumably alluvium above the water table in proximity to these two wells had become at least temporarily saturated by the rains.

\section{DISCUSSION OF A POSSIBLE DEPRESSION, CONING, IN THE WATER TABLE}

The signature of the $\mathrm{BH}-9$ neutron log approximately $100 \mathrm{ft}$ vertical depth (BH-9 is a slant hole) strongly suggests that the water table is depressed at the BH-9 well location, Figure 7. The neutron response of the borehole changes markedly above this level suggesting that the detector had emerged from the water. The $\mathrm{BH}-9$ wellbore ends in the sinkhole itself, Figure 1. A depression of the water table might be most observable in $\mathrm{BH}-9$. This $100 \mathrm{ft}$ depth is well below sea level.

An argument against the coning interpretation arises because the water in the $41 / 2$ inch, $11 \mathrm{lb} / \mathrm{ft}$ casing presumably was brine saturated and this column of higher density saturated brine is in equilibrium with the "fresh" water of the aquifer. The water column should lie deeper within the pipe than the outside water table. There should then be a second observable neutron response at the "actual water table near sea level". There is no clear neutron response at the sea level depth. The neutrons should penetrate well into the formation through the brine filled casing and the cemented $61 / 2$ in hole. The $13 \mathrm{ft}$ spatial. separation between the observed neutron response and the "expected" neutron response at mean sea level sea is well within the approximately 15 in influence of the neutron logging tool. The density response in the BH-9 well also shows a slight density increase response below $100 \mathrm{ft}$ vertical depth.

Also, modeling of production data from some wells discussed here and from nearby wells drilled later, indicated an average in situ permeability of 60 darcies. Little heterogeneity or anisotropy was assumed in that modeling (Ostensen, 1994,1995). Such permeability would imply a water table depression of only 0.014 in. No explanation can be given for the discrepancy between the log interpretation and the modeling of production data.

However, measured permeability of some alluvium sand samples were two orders of magnitude less than the calculated in situ values. Furthermore the earlier seismic data (Miller et al in Bauer, 1994) suggested that the 10-20 ft perturbations in the reflector near the sinkhole might be due to coning in the water table. 


\section{SHAPE OF THE ELECTRIC LOGS INFERS INFORMATION ABOUT THE SALINITY PROFILE OF AQUIFER ABOVE THE SALT DOME}

It was expected that the salinity of the aquifer above the salt dome would increase with depth from the top of the water table to the top of the salt dome itself. This should be observable in the resistivity $\log$, if the intrinsic electrical properties of the alluvium itself do not vary greatly with depth. Geologic descriptions of the core and the cuttings in the alluvium appear similar with depth (Bauer, 1994). Three resistivity logs were run in the course of the sinkhole diagnostic effort in the BH-3,5, and 6 holes. Generally, the resistivity of the electric log decreases with depth from the water table to the top of the salt, suggesting that the salinity of the aquifer increases with depth reaching a maximum right at the top of salt. The exception to this is the curve in $\mathrm{BH}-3$ where the value of the resistivity begins to increase approximately 35 feet below the water table and reaches a secondary maximum $50 \mathrm{ft}$ below the water table. This deviation may be correlated with a large washout which would have been filled with almost saturated brine drilling fluid suppressing the resistivity over that portion of this log. An exact resistivity analysis of the brine requires core properties that are not available.

The BH-5 electric log, Figure 3, traverses the formation from below the influence of the $34 \mathrm{ft}$ conductor pipe into the salt. The dielectric properties of the competent salt are reflected in the higher resistivity values as the log traverses from the saturated alluvium to the salt.

\section{CORRELATION OF LOG DATA WITH SEISMIC REFLECTORS}

Earlier high resolution seismic surveys suggested a strong reflector ranging from 50 to $150 \mathrm{ft}$ in depth across the entire survey area (Miller et al in Bauer, 1994). At the time the prominent reflection in the seismic data could not be associated with either water table or the top of salt. (Subsequent additional processing and three dimensional tomography later provided an association of this reflector with the water table.) It was felt that this prominent reflector might exist within the alluvium and not be associated with the "known" water table or the top of the salt dome. Could the logging program determine that a "prominent geological interface" (in addition to the water table or the top of the salt) existed in the alluvium and was correlatable to this reflector?

To find this reflector within the alluvium:

- The density log was examined for density changes within the alluvium.

- The sonic log was examined for changes in the depth display of velocity within the alluvium.

- The gamma ray log was examined for marked lithology changes within the alluvium.

- The neutron log was examined for changes of water saturation within the alluvium. 
- Attempts were made to correlate irregularities in the caliper log with the logs above to eliminate effects of borehole irregularities (rugosity).

The display of the density log through the alluvium was examined for changes which might indicate the presence of a reflector. The density log revealed an increase of density of $0.1-0.2 \mathrm{~g} / \mathrm{cc}$ from about $125-160 \mathrm{ft}$ and just near the top of the salt in a number of the wells. In two of the wells, $\mathrm{BH}-3$, and $\mathrm{BH}-5$, where caliper logs were available, this variation in density appeared correlative with the hole rugosity, and by inference this may account for variations in the density log in the other wells, although caliper logs are not available. However, it cannot be said that every variation in the density log was explained by hole rugosity. There are local density variations which might infer a reflector, but uncertainties cloud any attempt to draw conclusions. Large cemented washouts and the iron casing make it difficult to draw inferences about the possible presence of a reflector from the density log.

The open hole sonic log (amplitude, pressure wave velocity) showed little variation in the alluvium. The variable density log shows less uniformity in the alluvium than in the salt, but this could be influenced by hole rugosity.

The gamma ray log showed little discontinuity through the alluvium.

The neutron log showed some variations across the alluvium. It is difficult to say however, whether these irregularities were due to intrinsic changes of lithology (for example, hydrated clays vs. sand) or changes in water saturation. It should also be kept in mind that the sinkhole was a dynamic situation in that the sand level had been decreasing approximately $1 / 3 \mathrm{ft} /$ day. Approximately 1200 cubic yards of fill sand was added to the sinkhole. With these dynamics, unsaturated layers of the relatively incompetent sand could be transported below the water table and not be fully saturated at the time the logs were run. This would account for some unexplained variations in the neutron log should this have occurred adjacent to the boreholes. This local water saturation contrast in the sand may also account for signs of a reflector near the sinkhole.

\section{SUMMARY OF INFORMATION OBTAINED ABOUT WEEKS ISLAND DOME FROM LOGGING PROGRAM}

Near the sinkhole, the top of the salt dome was found to be between 187 and $190 \mathrm{ft}$ bgl. The upper portion of the salt dome does not appear to be fractured. Instead, it appears competent and flat.

The water table adjacent to the sinkhole appears between +1 and $+3 \mathrm{ft} \mathrm{msl} \mathrm{(except} \mathrm{for}$ BH-9). The saturation of the alluvium above the water table can be influenced by torrential rains and mask evidence of the water table. The salinity of the aquifer appears to increases steadily from the water table to the top of the salt. 
The neutron and density logs of $\mathrm{BH}-9$ suggest a 13 foot depression of the water table. This is contrary to permeabilities derived from production test data. No resolution of the discrepancy is offered.

The log data gives an account of the alluvium-salt interface and the water table, both possible seismic reflectors. No strong evidence for additional reflectors in the alluvium exists. However, interpretation of the available data does not preclude their presence. 


\section{REFERENCES}

Acres Intemational Corporation, 1987, Weeks Island Strategic Petroleum Reserve Geological Site Characterization Report, Albuquerque NM, Sandia National Laboratories Report Sand 87-7111, 175p.

Bauer, S. (editor), 1995, Update of Assessment of Geotechnical Risks: Strategic Petroleum Reserve Weeks Island Site, Sandia National Laboratories Report SAND 94-2629.

Ehgartner, B. L., 1993, Weeks Island Stress Predication and Relationship to Sinkhole Formation, Sandia National Laboratories Department 6113 internal memorandum, Oct. 1993, Albuquerque, NM.

Maartinez, J. D., 1995, "Weeks Island Mine Hydrology Prior to Oil Storage," Solution Mining Institute Meeting, spring meeting, New Orleans, Louisiana, 15 p, in Deerfield, Illinois meeting archives.

Martinez, J.; Thoms, R.; Kolb; C.; Kumar, M. B; Wilcox, R.; Newchurch, E.; 1978, “An Investigation of the Utility Of gulf Coast Salt Domes for the Storage or Disposal Of Radioactive Wastes," Volume 1 , Prepared for the U. S. Department of Energy by the Institute for Environmental Studies, Louisiana State University, December 1978.

Miller, R.; Jainghai, X.; Anderson, J.; Laflen, J.; Erickson, J.; Acker, P.; Brohammer, M.; Steeples, D.; and Black, R.; 1994, "High Resolution Seismic Reflection Survey near SPR Surface Collapse Feature at Weeks Island, Louisiana," in Bauer, 1995, 39p.

Neal, J.; Bauer S.; Eghartner, B.; 1995, "Sinkhole Progression at the Weeks Island, Louisiana, Strategic Petroleum (SPR) Site," Solution Mining Research Institute fall meeting, San Antonio TX, 16p, in Deerfield, Illinois meeting archives.

Ostensen, $R, 1994-1995$ Series of Internal Department 6113 Sandia National Laboratories internal memoranda, March, August, September, December, 1994, January 1995, Albuquerque, NM.

Staatz, T, 1996, Colog Inc., internal neutron tool tests and calibrations.

Yearsley, E. N. Crowder, R. E. and Irons, L. A., 1991, "Monitoring Well Completion Evaluation with Borehole Geophysical Density Logging, Ground Water Monitoring Review," Winter 1991 Issue, 12 p. 
Intentionally left blank 
TABLE 1

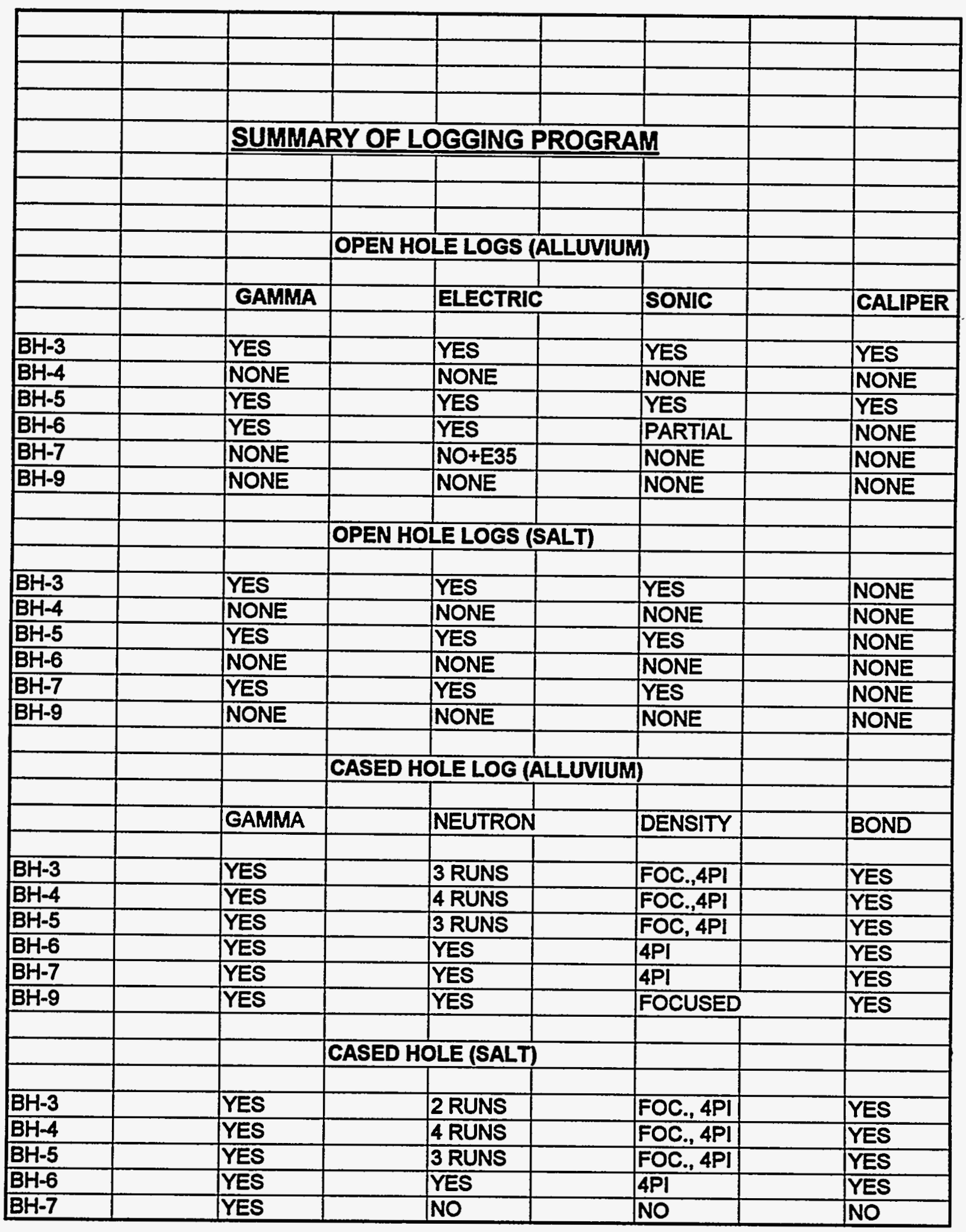


TABLE 2 Weeks Island Salt and Water Table Correlations at Sinkhole*

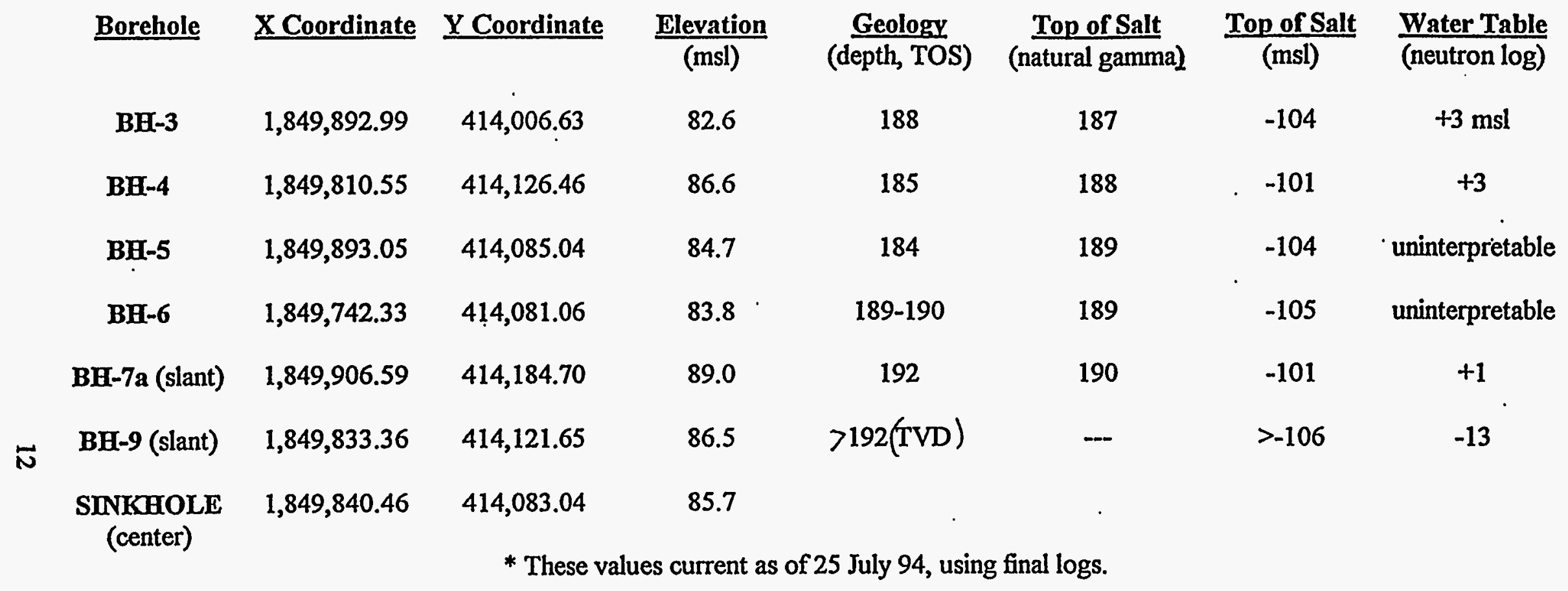




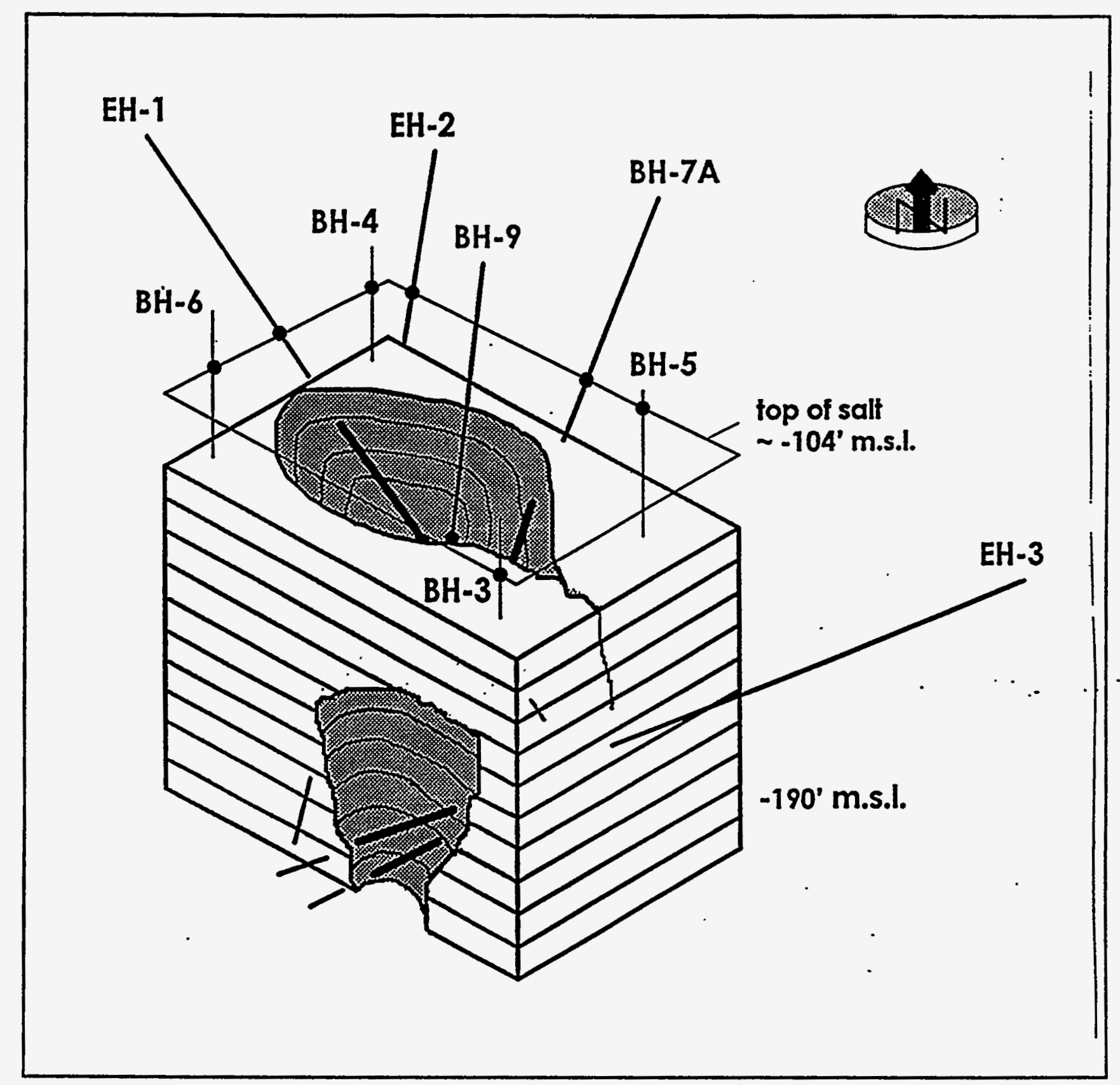

Figure 1 Diagrammatic representation of exploratory drilling and geometry of Sinkhole \#1 throat. Boreholes 'BH-3, 4, 5, and 6 were drilled for crosswell seismic tomography; slantholes BH-7A and 9 were drilled for throat definition. EH-1, 2, and 3 further defined the throat and provided decisive information regarding grouting potential. Accentuated portions of boreboles define throat penetrations. 


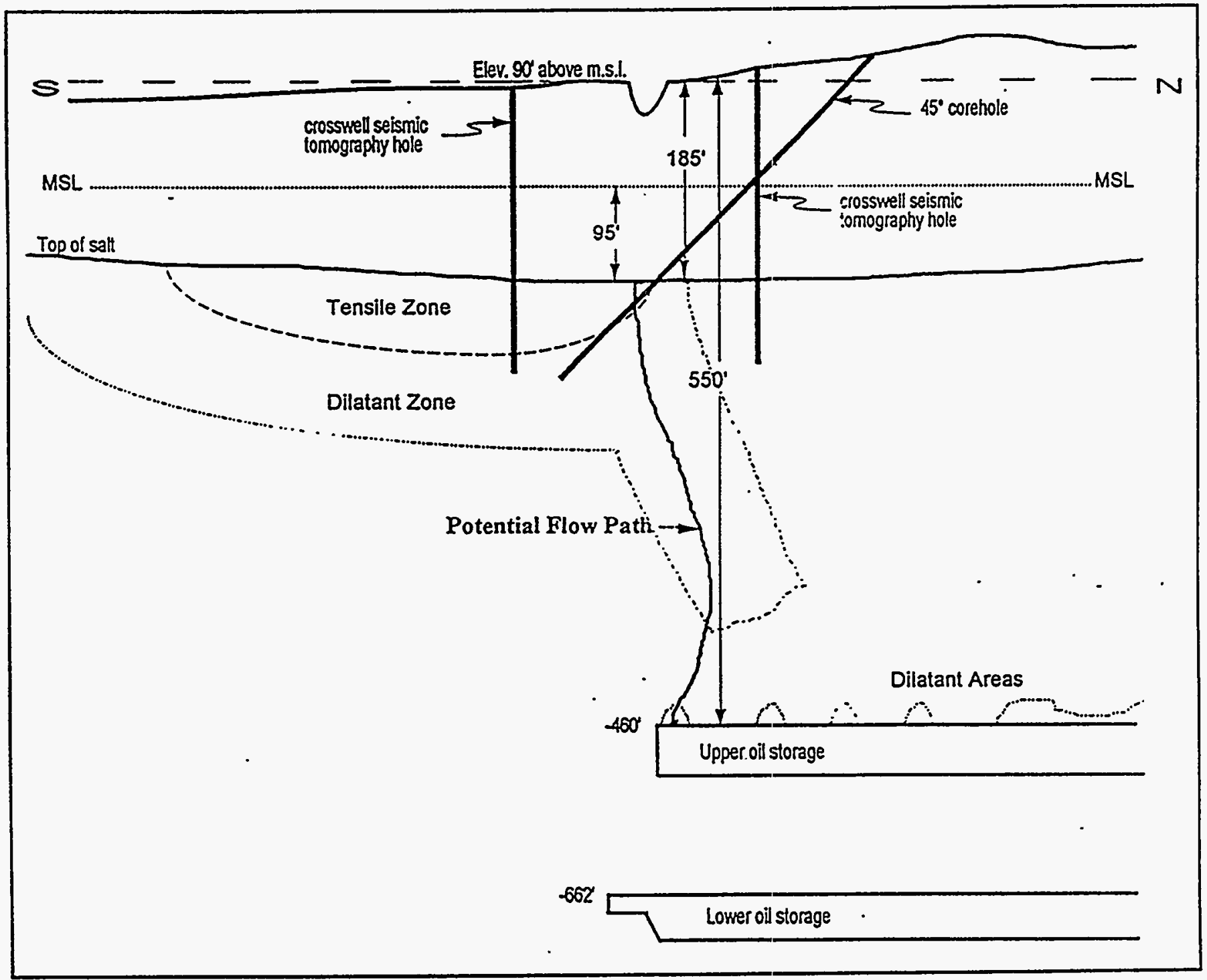

Figure 2 Geomechanical modeling by Ehgartner (1993) showed mechanism for crack development in tension zone that would develop over mined openings after a number of years, and progressing through weakened dilatant zone. Based largely on these modeling results, crosswell tomography was conducted and angled boreholes were planned to intersect such features. 


\section{SI}

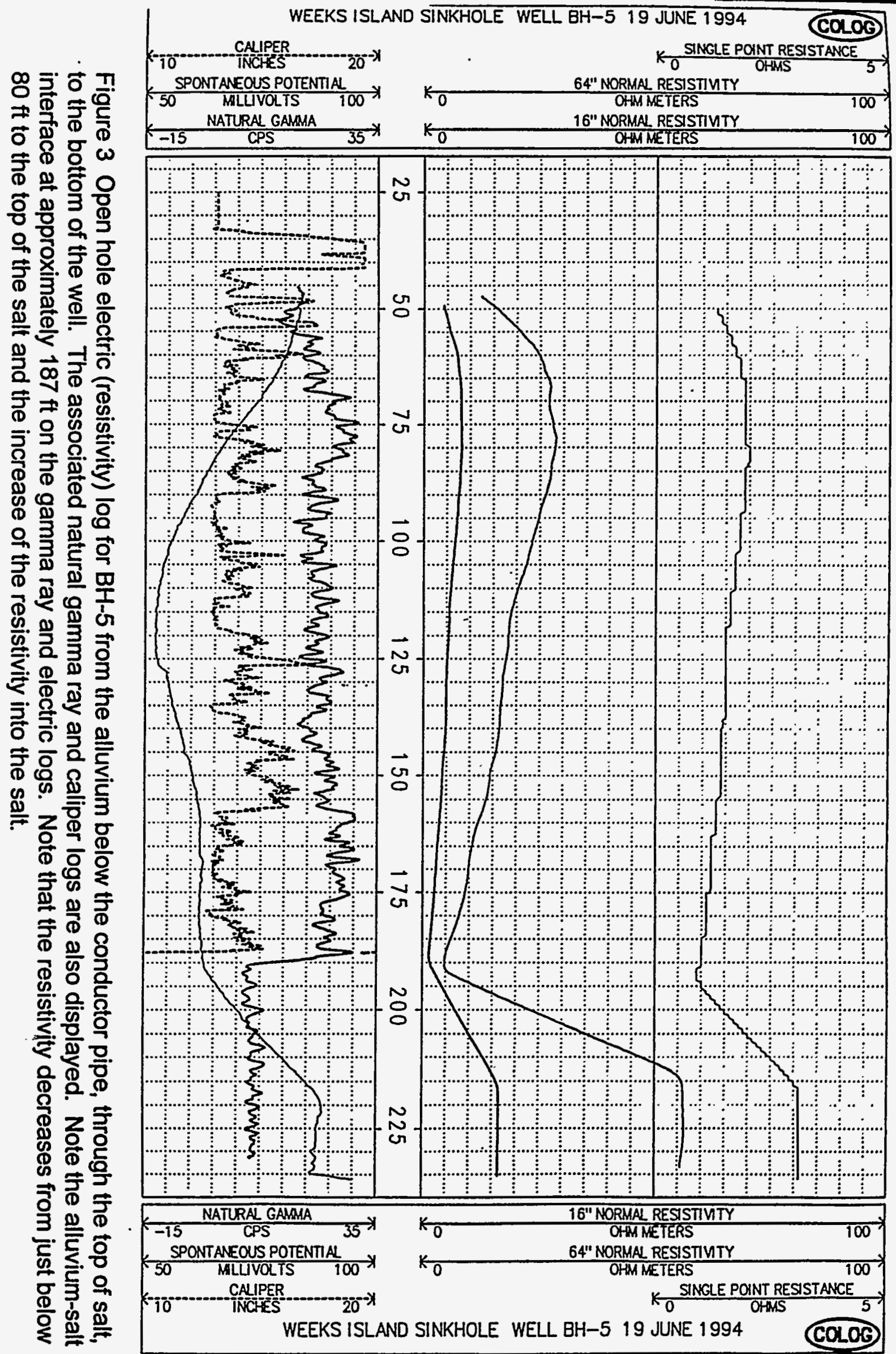




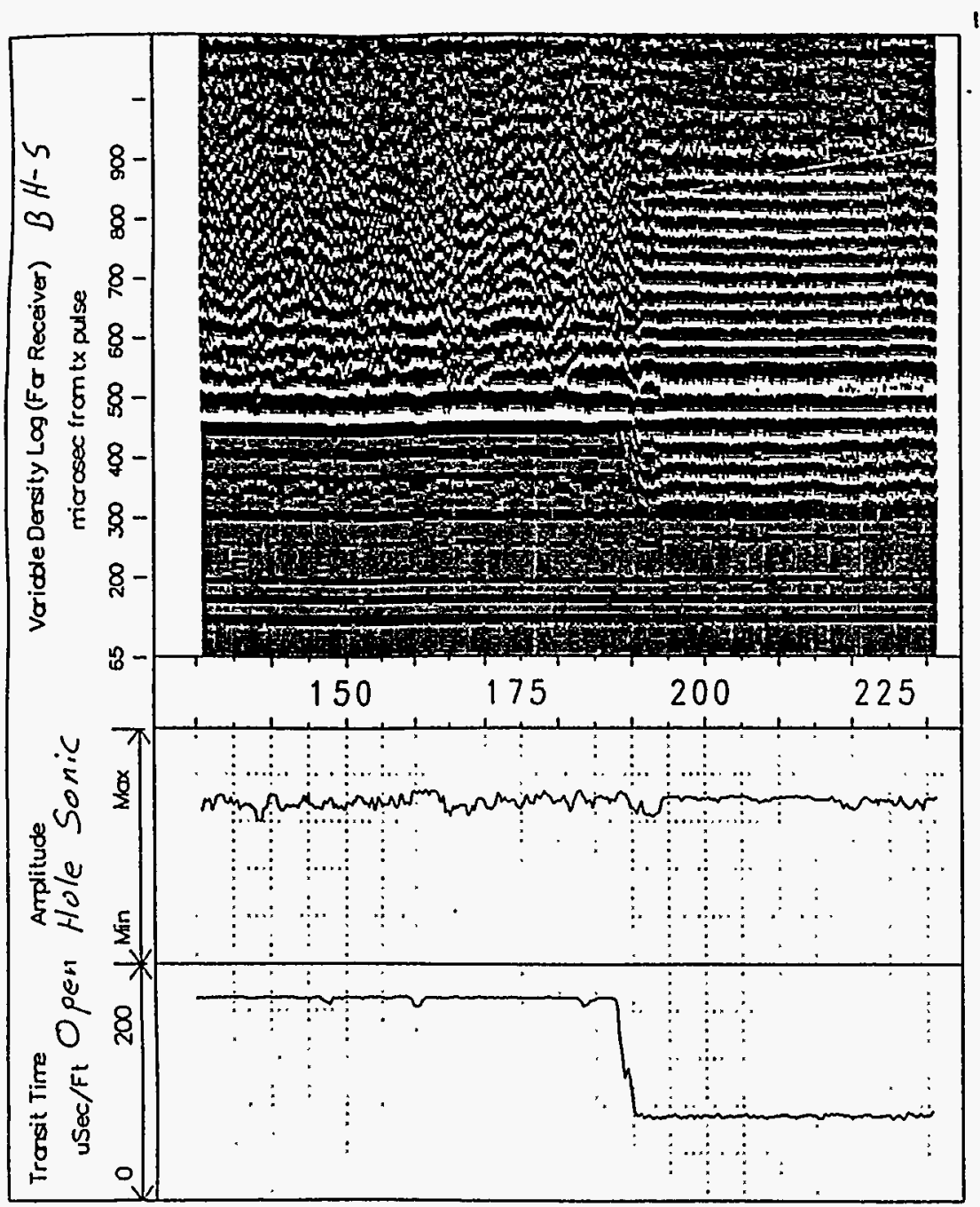

Figure 5. Open hole sonic log in BH-5. Note the sharp change in transit time at about $189 \mathrm{ft}$ as the log traverses from the alluvium to the salt. Except for the alluvium-salt interface, the transit time, amplitude display are rather uniform. Within the salt the variable density display is quite uniform but less so within the alluvium. 


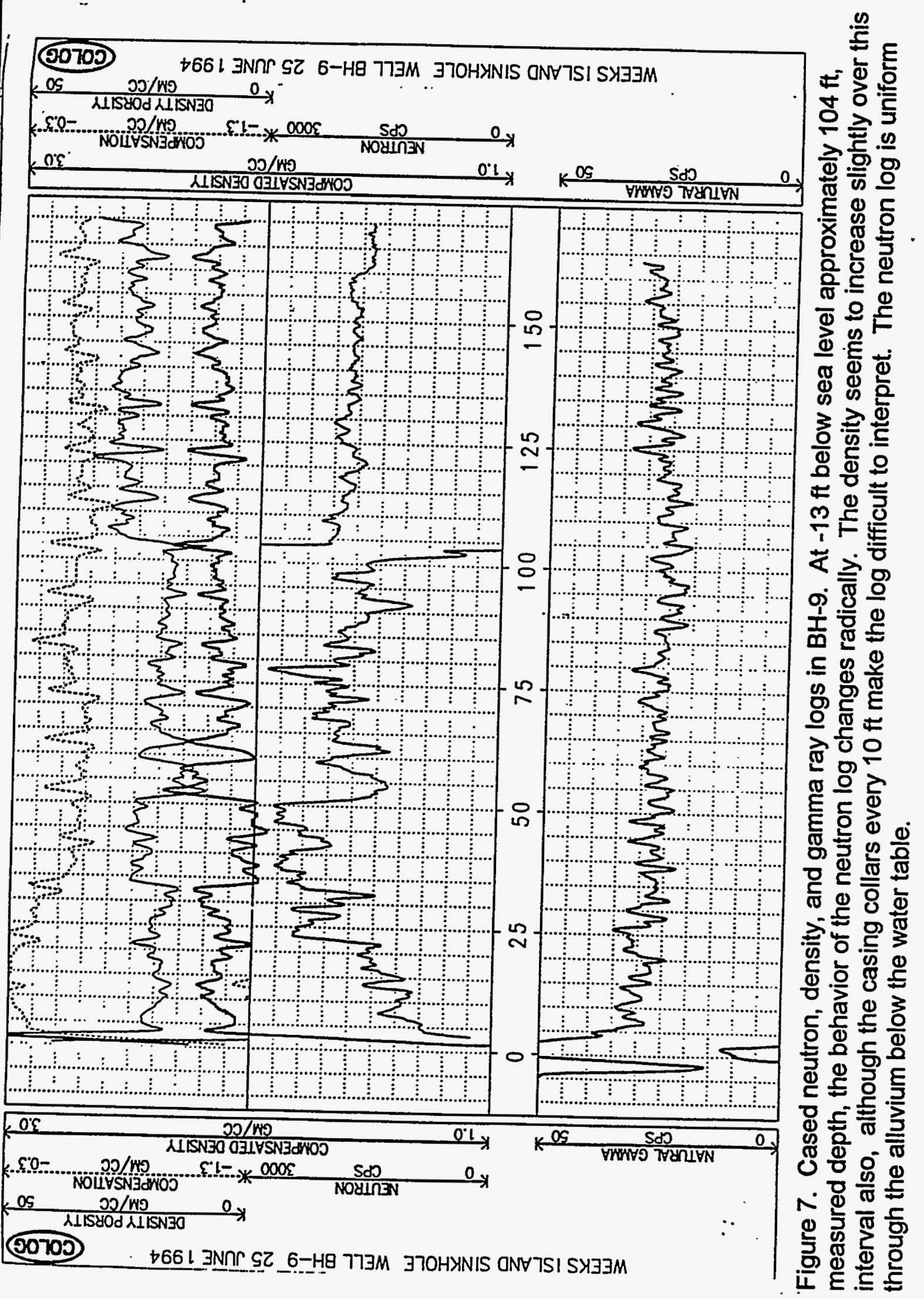


Intentionally left blank 
Distribution:

U.S. DOE SPR PMO (7)

900 Commerce Road East

New Orleans, LA 70123

Attn: G. B. Berndsen, FE 443.1

J. Culbert, FE 4431

R. E. Myers, FE 4422 (3) TDCS (2)

Tucker \& Associates, Inc. 800 Commerce Road West Suite 500

New Orleans, LA 70123

Attn: C. Sherman

U.S. Department of Energy (2)

Strategic Petroleum Reserve 1000 Independence Avenue SW Washington, D.C. 20585

Attn: D. Johnson

D. Buck

DynMcDermott (2)

850 South Clearview Parkw;ay

New Orleans, LA 70123

Attn: B. Gump

K. Mills

Weeks Island SPR Site (2)

P.O. Box 434

New Iberia, LA 70560

M. Bertoldi

M. Jackson

Sandia Internal:

MS 0701 R. W. Lynch, 6100

MS 1033 D. Glowka, 6111

MS $1033 \mathrm{~T}$. Finger, 6111

MS 1033 R. Jacobson, 6111

MS 0706 J. K. Linn, 6113 (10)

MS 0706 S. J. Bauer, 6113

MS 0706 B. L. Ehgartner, 6113

MS 0706 T. E. Hinkebein, 6113
MS 0706 J. T. Neal, 6113

MS 0705 R. S. Harding, 6114

MS 0705 D. G. Keefe, 6114

MS 0750 M. C. Walck, 6116

MS 0750 S. Ballard, 6116

MS 9018 Central Tech. Files, 8523-2

MS 0899 Technical Library, 4414 (5)

MS 0619 Review \& Approval Desk, (2) 12630 for DOE/OSTI 